\title{
PENGARUH MEKANISME CORPORATE GOVERNANCE TERHADAP NILAI PERUSAHAAN PADA PERUSAHAAN CONSUMER GOODS
}

\author{
Kartika Aprilia Benhardy \\ Program Studi Magister Manajemen Universitas Tarumanagara \\ kbenhardy@gmail.com
}

\begin{abstract}
The purpose of this study was to examine the effect of corporate governance mechanisms on firm value. Proxy of corporate governance variables is managerial ownership, institutional ownership, board of directors, independent board of commissioner and audit committee. The research sample is consumer goods company listed on BEI in 2012-2016. The sampling technique used is purposive sampling to get 27 companies from 40 consumer goods companies listed on BEI with total of observation is 135 observation data during 5 years. Data analysis techniques using multiple regression analysis panel data by Eviews 9 software. Firm value is measured using Tobin's Q. In addition, hypothesis testing was performed using t-statistic with significance level of 5\%. Company value is measured using Tobin's Q. Based on the results of the analysis, it is found that managerial and independent board ownership variables have a negative and significant influence on firm value. Institutional ownership variables have a positive and significant influence on firm value. While the other two variables, the board of directors and audit committee has no significant effect on firm value.
\end{abstract}

Keywords: Corporate Governance, Managerial Ownership, Institutional Ownership, Board of Directors, Independent Board of Commissioners, Audit Committee and Firm Value.

\section{PENDAHULUAN}

Dalam mengelola perusahaannya, pihak manajemen tentunya memiliki tujuan yang ingin dicapai. Ada yang bertujuan memperolah laba yang sebesar-besarnya, ada yang ingin mempertahankan eksistensi perusahaannya, ada yang ingin memakmurkan pemilik perusahaan atau para pemegang saham, dan ada pula yang bertujuan memaksimalkan nilai perusahaan (Anggraini, 2013) yang tercermin pada harga saham. Upaya yang dapat dilakukan oleh perusahaan untuk memaksimalkan keuntungannya adalah dengan mempercayakan pengelolaan perusahaannya kepada tenaga ahli dan profesional yang biasa disebut manajer. Namun, penunjukkan manajer sebagai pengelola perusahaan ternyata dapat memunculkan suatu konflik keagenan dimana antara pemegang saham dan manajer memiliki kepentingan dan tujuan berbeda yang hendak dicapai. Pihak manajer (agen), dengan kewenangan yang dimilikinya bisa bertindak untuk kepentingan pribadinya dan mengorbankan kepentingan para pemegang saham (Trisnantari, 2010). Untuk meminimalisir munculnya konflik keagenan dan pemegang saham perusahaan dapat terus memantau perusahaan maka dibutuhkan suatu instrumen tata kelola perusahaan yang disebut corporate governance. Corporate governance merupakan suatu sistem yang mengatur dan mengendalikan perusahaan yang diharapkan dapat memberikan dan meningkatkan nilai perusahaan kepada para pemegang saham (Aldino, Yusralaini, \& Paulus, 2015). Sistem ini menyelaraskan kepentingan antara manajemen dengan pemilik perusahaan, sehingga manajemen akan bekerja lebih efektif dan efisien dalam menghasilkan profit bagi perusahaan (Sari \& Sedianingsih, 2014). Corporate governance sangat penting untuk dilaksanakan di dalam 
perusahan-perusahaan, karena bisa memberikan pengaruh postif pada kinerja dan nilai perusahaan tersebut (Klapper \& Love, dalam Surya dan Yustiavandana, 2006).

Dalam konsep corporate governance, terdapat dua hal yang perlu ditekankan. Yang pertama, pemegang saham (shareholder) berhak memperoleh informasi secara benar dan tepat. Kedua, perusahaan memiliki kewajiban untuk mengungkapkan segala informasi tentang perusahaan secara lengkap, tepat, akurat dan transparan kepada seluruh pamangku kepentingan (stakeholder). baik itu pemerintah, investor, kreditor, supplier, maupun masyarakat umum. Menurut Rofina dan Priyadi (2013), implementasi corporate governance merupakan bentuk lain dari penegakan etika bisnis dan etika kerja yang sudah sejak lama menjadi komitmen bagi perusahaan dan diharapkan implementasi ini dapat meningkatkan citra dan nilai perusahaan ke depannya. Di dalam corporate governance terdapat dua mekanisme yang digunakan dalam penerapannya, yaitu mekanisme internal dan mekanisme eksternal. Mekanisme yang digunakan sebagai variabel pada penelitian ini adalah kepemilikan manajerial, kepemilikan institusional, dewan direksi, dewan komisaris independen dan komite audit. Stuktur kepemilikan dipercaya dapat mempengaruhi jalannya suatu perusahaan sehingga dapat mencapai tujuan perusahaan, yaitu memaksimalkan nilai perusahaan. Dewan direksi dan dewan komisaris berperan dalam mengawasi kinerja manajemen dan memastikan tata kelola perusahaan telah dijalankan dengan baik. Komite audit memiliki tanggung jawab dalam mengawasi laporan keuangan, audit eksternal dan sistem pengendalian internal. Dengan adanya komite audit maka laporan keuangan telah diawasi sehingga kinerja keuangan pun terkontrol sehingga berdampak baik juga untuk nilai perusahaan (Ningtyas, Suhadak, \& Nuzula, 2014).

Penelitian ini berbeda dengan penelitian sebelumnya dimana jangka waktu sampel yang diambil lebih panjang, yaitu antara tahun 2012-2016. Penelitian ini menggunakan perusahaan manufaktur yang bergerak dibidang consumer goods (barang konsumsi). Perusahaan consumer goods adalah perusahaan yang menyediakan barang yang banyak digunakan atau dikonsumsi oleh masyarakat untuk kebutuhan sehari-hari. Karakteristik dari perusahaan yang tergabung ke dalam sektor consumer goods ini, memiliki tingkat persaingan antar perusahaan yang cukup tinggi khususnya dalam memasarkan produknya kepada konsumen. Hal ini membuat perusahaan dituntut untuk dapat terus meningkatkan daya saingnya agar selalu unggul dari kompetitor. Perusahaan pada sektor consumer goods, menjadi salah satu pilihan utama bagi investor sehingga investor memiliki fokus yang lebih terhadap perusahaan consumer goods karena setiap permasalahan yang terjadi pada perusahaan ini, seperti penurunan penjualan, penurunan kualitas produk, kekurangan persediaan, permasalahan limbah (waste) dan lainnya dapat mempengaruhi perubahan harga saham perusahaan.

\section{HIPOPTESIS}

H1: Kepemilikan Manajerial memiliki pengaruh yang signifikan terhadap Nilai Perusahaan.

H2: Kepemilikan Institusional memiliki pengaruh yang signifikan terhadap Nilai Perusahaan.

H3: Dewan direksi memiliki pengaruh yang signifikan terhadap Nilai Perusahaan.

H4: Dewan Komisaris Independen memiliki pengaruh yang signifikan terhadap Nilai Perusahaan.

H5: Komite Audit memiliki pengaruh yang signifikan terhadap Nilai Perusahaan.

H6: Kepemilikan Manajerial, Kepemilikan Institusional, Dewan Direksi, Dewan Komisaris Independen dan Komite Audit memiliki pengaruh yang signifikan terhadap Nilai Perusahaan. 


\section{Kerangka Pemikiran}

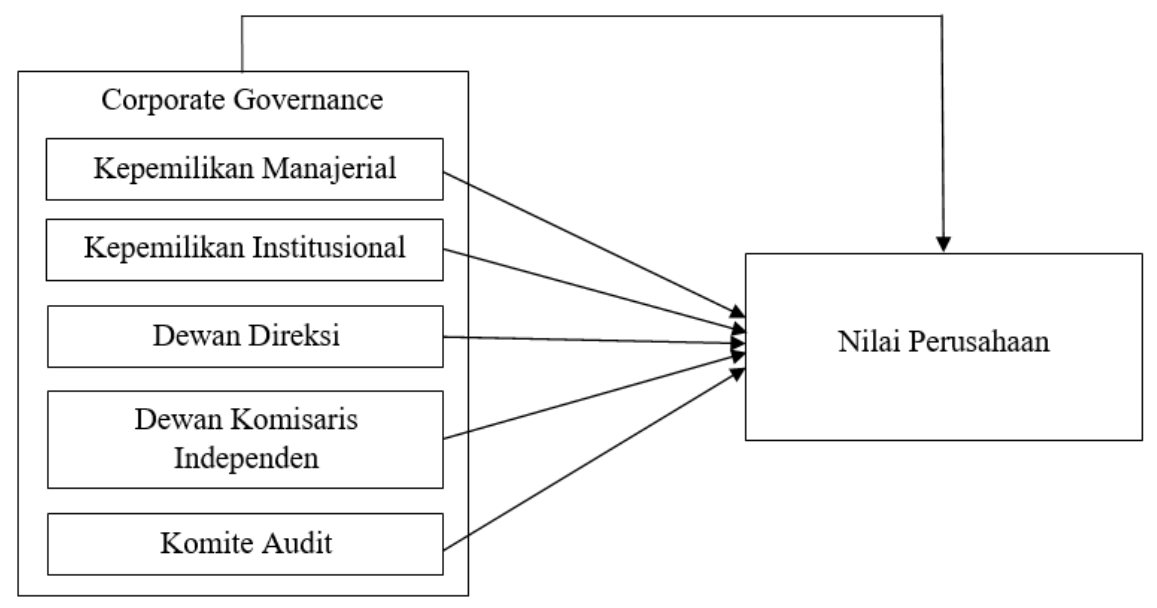

Gambar 1. Kerangka Pemikiran

\section{METODE PENELITIAN}

Jenis penelitian yang digunakan adalah penelitian eksplanatori (explanatory research). Singarimbun dan Effendi (2006) menjelaskan bahwa explanatory research, yaitu penelitian yang digunakan untuk menjelaskan hubungan kausal antara variabel-variabel melalui pengujian hipotesa yang dirumuskan. Unit analisis pada penelitian ini adalah perusahaan-perusahan yang bergerak di sektor industri consumer goods yang sudah menerapkan corporate governance dan terdaftar di Bursa Efek Indonesia pada periode tahun 2012 hingga 2016. Teknis analisis data yang digunakan adalah analisis regresi berganda data panel dengan bantuan software Eviews 9. Data panel adalah data gabungan antara data cross section dan time series (Astuti, 2010). Selain itu, juga dilakukan uji hipotesis menggunakan tstatistik dengan tingkat signifikansi sebesar 5\%.

Pengambilan sampel penelitian ini dilakukan dengan menggunakan metode purposive sampling, yaitu teknik pengambilan sampel melalui pertimbangan tertentu dengan cara menetapkan kriteria yang sesuai dengan tujuan penelitian. Sampel yang diperoleh sebanyak 27 perusahaan dari 40 perusahaan consumer goods yang terdaftar di BEI dengan total pengamatan, yaitu 135 data observasi selama 5 tahun.

\section{Statistik Deskriptif}

Statistik deskriptif merupakan gambaran atau deskripsi suatu data yang dilihat berdasarkan nilai rata-rata (mean), standar deviasi, variance, maksimum, minimum, sum, range, kurtosis dan skewness (kemencengan distribusi) (Ghozali, 2009).

\section{Pemilihan Model Regresi}

\section{Pooled Least Square atau Common Effect Model}

Pooled Least Square atau Common Effect Model merupakan pendekatan model data panel yang mengkombinasikan data time series dan cross section dengan pendekatan OLS (Ordinary Least Square) untuk mengestimasi parameternya.

\section{Fixed Effect Model}

Model fixed effect merupakan pendekatan model data panel yang mengasumsikan bahwa perbedaan antar individu dapat diakomodasi dari perbedaan intersepnya. Untuk mengestimasi data panel model fixed effects menggunakan teknik variabel dummy untuk menangkap perbedaan intersep antar individu. 


\section{Random Effect Model}

Model random effect merupakan pendekatan model data panel yang mengestimasikan data panel dimana variabel gangguan mungkin saling berhubungan antar waktu dan antar individu. Pada model random effect perbedaan intersep diakomodasi oleh error terms masing-masing individu.

\section{Pemilihan Model Estimasi}

a. Uji Chow (Chow Test)

Chow test adalah pengujian untuk menentukan Ordinary Least Square (Common Effect) atau model Fixed Effect yang paling tepat digunakan dalam mengestimasi data panel dengan melakukan uji hipotesis sebagai berikut:

$\mathrm{H}_{0} \quad$ : Memilih model Common Effect

$\mathrm{H}_{\mathrm{a}} \quad$ : Memilih model Fixed Effect

Apabila Prob Cross-section $F$ dan Cross-section Chi-square $<0.05$ pada tingkat signifikan $5 \%$, maka $\mathrm{H}_{0}$ ditolak dan $\mathrm{H}_{\mathrm{a}}$ diterima sehingga model yang dipilih untuk diproses lebih lanjut adalah Fixed Effect Model.

b. Uji Hausman (Hausman Test)

Hausman test adalah pengujian statistik untuk memilih apakah model Fixed Effect atau Random Effect yang paling tepat digunakan dengan melakukan uji hipotesis sebagai berikut:

$\mathrm{H}_{0} \quad$ : Memilih model Random Effect

$\mathrm{H}_{\mathrm{a}} \quad$ : Memilih model Fixed Effect

Apabila Cross-section random $<0.05$ pada tingkat signifikan 5\%, maka $\mathrm{H}_{0}$ ditolak dan $\mathrm{H}_{\mathrm{a}}$ diterima sehingga model yang dipilih untuk diproses lebih lanjut adalah Fixed Effect Model.

\section{Analisis Regresi Berganda}

Analisis data yang digunakan dalam penelitian ini menggunakan teknik analisis regresi linear berganda. Analisis linear berganda digunakan untuk mengetahui ada tidaknya pengaruh dari variabel independen terhadap variabel dependen. Persamaan regresi yang digunakan dalam penelitian ini adalah sebagai berikut:

Keterangan:

$$
\mathrm{Q}=\alpha+\beta_{1} \mathrm{KPM}+\beta_{2} \mathrm{KPI}+\beta_{3} \mathrm{DD}+\beta_{4} \mathrm{DKI}+\beta_{5} \mathrm{KA}+\varepsilon
$$

Q : Nilai perusahaan

KPM : Kepemilikan Manajerial

KPI : Kepemilikan Institusional

DD : Dewan Direksi

DKI : Dewan Komisaris Independen

KA : Komite Audit

$\alpha \quad$ : Konstanta

$\beta_{1}-\beta_{5}:$ Koefisien Regresi

$\varepsilon \quad:$ Error

\section{Uji Hipotesis Statistik}

\section{Uji Parsial (Uji-t)}

Uji t digunakan untuk mengetahui apakah variabel-variabel independen secara parsial berpengaruh nyata atau tidak terhadap variabel dependen. Derajat signifikansi yang digunakan adalah sebesar 5\% atau 0,05. Apabila nilai signifikan lebih kecil dari derajat kepercayaan maka kita menerima hipotesis alternatif, yang menyatakan bahwa suatu variabel independen secara parsial mempengaruhi variabel dependen. 


\section{Uji Simultan (Uji-F)}

Uji F digunakan untuk mengetahui apakah variabel-variabel independen secara simultan berpengaruh signifikan terhadap variabel dependen. Derajat kepercayaan yang digunakan adalah sebesar 5\% atau 0.05. Apabila nilai $\mathrm{F}$ hasil perhitungan lebih besar daripada nilai $\mathrm{F}$ menurut tabel maka hipotesis alternatif, yang menyatakan bahwa semua variabel independen secara simultan berpengaruh signifikan terhadap variabel dependen.

\section{Uji Koefisien Determinasi}

Koefisien determinasi menjelaskan seberapa besar perubahan atau variasi suatu variabel bisa dijelaskan oleh perubahan atau variasi pada variabel yang lain atau dapat dikatakan seberapa besar kemampuan variabel bebas untuk berkontribusi terhadap variabel tetapnya dalam satuan persentase. Nilai koefisien ini antara 0 dan 1, jika hasil lebih mendekati angka 0 berarti kemampuan variabel-variabel independen dalam menjelaskan variasi variabel amat terbatas. Tapi jika hasil mendekati angka 1 berarti variabel-variabel independen memberikan hampir semua informasi yang dibutuhkan untuk memprediksi variasi variabel dependen.

\section{HASIL DAN PEMBAHASAN}

\section{Statistik Deskriptif}

Analisis deskriptif memberikan gambaran tentang data yang diperoleh. Gambaran data ini dapat menjadi acuan untuk melihat karakteristik data yang dimiliki. Analisis statistik deskriptif pada penelitian ini bertujuan untuk menggambarkan karakteristik data yang disajikan, yaitu nilai rata-rata (mean), nilai minimum, nilai maksimum dan nilai standar deviasi dari variabel corporate governance (kepemilikan manajerial, kepemilikan institusional, dewan direksi, dewan komisaris independen dan komite audit) dan variabel nilai perusahaan. Hasil pengolahan statistik deskriptif dapat dilihat pada tabel berikut:

Tabel 1. Descriptive Statistics

\begin{tabular}{|l|r|r|r|r|r|}
\hline & \multicolumn{1}{|c|}{$\mathrm{N}$} & Minimum & Maximum & \multicolumn{1}{c|}{ Mean } & Std. Deviation \\
\hline KM & 135 & .0000 & .2522 & .027560 & .0666801 \\
KI & 135 & .3307 & .9977 & .764880 & .1659629 \\
DD & 135 & 3.0000 & 16.0000 & 5.303704 & 2.5075232 \\
DKI & 135 & .2000 & .8000 & .398336 & .1097030 \\
KA & 135 & 2.0000 & 4.0000 & 3.051852 & .3523592 \\
Q & 135 & .4071 & 18.6404 & 3.258914 & 4.0226492 \\
Valid N (listwise) & 135 & & & & \\
\hline
\end{tabular}

Sumber: Hasil Pengolahan Data Peneliti (2017)

\section{Pemilihan Model Analisis Data Panel Uji Chow}

Dari hasil output analisis diperoleh bahwa nilai Prob Cross-section F dan Crosssection Chi-square lebih kecil dari nilai alpha 0.05, yaitu sebesar 0.000 . Hal ini berarti bahwa $\mathrm{H}_{0}$ ditolak dan $\mathrm{H}_{\mathrm{a}}$ diterima sehingga model yang dipilih dan lebih tepat digunakan dalam penelitian ini adalah fixed effect model dibanding dengan common effect model.

\section{Uji Hausman}

Dari hasil output analisis diperoleh bahwa nilai Cross-section random lebih kecil dari nilai alpha 0.05 , yaitu sebesar 0.000 . Hal ini berarti bahwa $\mathrm{H}_{0}$ ditolak dan $\mathrm{H}_{\mathrm{a}}$ diterima sehingga model yang dipilih dan lebih tepat digunakan dalam penelitian ini adalah fixed effect model dibanding dengan random effect model. 


\begin{tabular}{|c|c|c|c|c|}
\hline \multicolumn{5}{|c|}{$\begin{array}{l}\text { Dependent Variable: Q } \\
\text { Method: Panel Least Squares } \\
\text { Date: } 12 / 04 / 17 \text { Time: } 14: 53 \\
\text { Sample: } 20122016 \\
\text { Periods included: } 5 \\
\text { Cross-sections included: } 27 \\
\text { Total panel (balanced) observations: } 135\end{array}$} \\
\hline Variable & Coefficient & Std. Error & t-Statistic & Prob. \\
\hline $\mathrm{C}$ & -16.98212 & 9.248338 & -1.836235 & 0.0692 \\
\hline KM & -32.92193 & 13.74693 & -2.394858 & 0.0184 \\
\hline $\mathrm{KI}$ & 34.36321 & 11.38474 & 3.018358 & 0.0032 \\
\hline DD & 0.603847 & 1.580739 & 0.382003 & 0.7032 \\
\hline DKI & -7.613427 & 3.067531 & -2.481939 & 0.0147 \\
\hline KA & -2.758425 & 2.544375 & -1.084127 & 0.2808 \\
\hline \multicolumn{5}{|c|}{ Effects Specification } \\
\hline \multicolumn{5}{|c|}{ Cross-section fixed (dummy variables) } \\
\hline R-squared & 0.866032 & \multicolumn{2}{|c|}{ Mean dependent var } & 3.258917 \\
\hline Adjusted R-squared & 0.825712 & \multicolumn{2}{|c|}{ S.D. dependent var } & 4.022651 \\
\hline S.E. of regression & 1.679371 & \multicolumn{2}{|c|}{ Akaike info criterion } & 4.078244 \\
\hline Sum squared resid & 290.4896 & \multicolumn{2}{|c|}{ Schwarz criterion } & 4.766902 \\
\hline Log likelihood & -243.2815 & \multicolumn{2}{|c|}{ Hannan-Quinn criter. } & 4.358095 \\
\hline F-statistic & 21.47872 & \multirow{2}{*}{\multicolumn{2}{|c|}{ Durbin-Watson stat }} & 1.153297 \\
\hline Prob(F-statistic) & 0.000000 & & & \\
\hline
\end{tabular}

Gambar 2. Hasil Output Fixed Effect Model

Sumber: Hasil Pengolahan Data Peneliti (2017)

\section{Analisis Regresi Berganda}

Berdasarkan hasil perhitungan yang dilakukan dengan menggunakan fixed effect model yang merupakan model terpilih pada penelitian ini, maka persamaan regresi linear berganda adalah sebagai berikut:

$$
\begin{aligned}
\mathrm{Q}_{i t}=-16.98212-32.92193 \mathrm{KM}_{i t}+ & 34.36321 \mathrm{KI}_{i t}+0.603847 \mathrm{DD}_{i t}-7.613427 \mathrm{DKI}_{i t}- \\
& 2.758425 \mathrm{KA}_{i t}
\end{aligned}
$$

Keterangan :

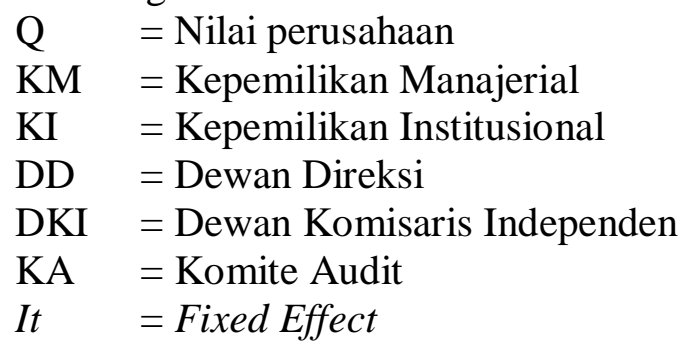

\section{Hipotesis Statistik}

Uji Parsial (Uji-t)

Berdasarkan hasil dari uji chow dan uji hausman yang dilakukan dalam penelitian ini, maka model regresi yang paling tepat digunakan untuk uji t adalah fixed effect model.

Berdasarkan hasil uji statistik, variabel kepemilikan manajerial memiliki tingkat signifikansi sebesar 0.0184 yang berarti lebih kecil dari nilai alpha 0.05 sehingga dapat disimpulkan bahwa variabel kepemilikan manajerial secara parsial memiliki pengaruh negatif dan signifikan terhadap nilai perusahaan. Variabel kepemilikan institusional memiliki tingkat signifikansi sebesar 0.0032 yang berarti lebih kecil dari nilai alpha 0.05 sehingga dapat disimpulkan bahwa variabel kepemilikan institusional secara parsial memiliki pengaruh positif dan signifikan terhadap nilai perusahaan. Variabel dewan direksi memiliki tingkat signifikansi sebesar 0.7032 yang berarti lebih besar dari nilai alpha 0.05 sehingga dapat disimpulkan bahwa variabel dewan direksi secara parsial tidak memiliki pengaruh yang signifikan terhadap nilai perusahaan. Variabel dewan komisaris independen memiliki tingkat 
signifikansi sebesar 0.0147 yang berarti lebih kecil dari nilai alpha 0.05 sehingga dapat disimpulkan bahwa variabel dewan komisaris independen secara parsial memiliki pengaruh negatif dan signifikan terhadap nilai perusahaan. Variabel komite audit memiliki tingkat signifikansi sebesar 0.2808 yang berarti lebih besar dari nilai alpha 0.05 sehingga dapat disimpulkan bahwa variabel komite audit secara parsial tidak memiliki pengaruh yang signifikan terhadap nilai perusahaan.

\section{Uji Simultan (Uji-F)}

Uji $F$ digunakan untuk mengetahui apakah variabel-variabel independen secara simultan berpengaruh signifikan terhadap variabel dependen. Berdasarkan hasil uji statistik F pada tabel fixed effect model, didapatkan hasil bahwa hasil output regresi menunjukkan nilai signifikansi sebesar $0.000<0.05$, sehingga dapat disimpulkan bahwa secara simultan variabel kepemilikan manajerial, kepemilikan institusional, dewan direksi, dewan komisaris independen dan komite audit memiliki pengaruh yang signifikan terhadap nilai perusahaan. Berdasarkan penjelasan tersebut, dapat disimpulkan bahwa $\mathrm{H}_{0}$ ditolak dan $\mathrm{H}_{\mathrm{a}}$ diterima karena terbukti dari hasil tersebut bahwa secara bersama-sama variabel independen memiliki pengaruh yang signifikan terhadap variabel dependen.

\section{Uji Koefisien Determinasi}

Koefisien determinasi digunakan untuk mengetahui seberapa besar kemampuan variabel bebas untuk berkontribusi terhadap variabel tetapnya dalam satuan persentase. Berikut adalah hasil perhitungan koefisien determinasi. Berdasarkan tabel fixed effect model, didapatkan hasil bahwa koefisien determinasi pada hasil output regresi menunjukkan nilai $R$ square sebesar 0.866 . Hal ini berarti bahwa kemampuan variabel independen yang terdiri dari kepemilikan manajerial, kepemilikan institusional, dewan direksi, dewan komisaris independen dan komite audit dalam menjelaskan variabel dependen nilai perusahaan adalah sebesar $86.6 \%$ dan sisanya sebesar $13.4 \%$ dijelaskan oleh variabel lain di luar variabel yang diteliti.

\section{Implikasi Penelitian}

Berdasarkan hasil pengolahan data dengan menggunakan fixed effect model, maka implikasi hasil penelitian dapat diuraikan sebagai berikut:

\section{Pengaruh Kepemilikan Manajerial terhadap Nilai Perusahaan}

Hasil pengujian untuk hipotesis pertama menunjukkan bahwa kepemilikan manajerial memiliki pengaruh negatif dan signifikan terhadap nilai perusahaan. Hal ini dapat dilihat dari tingkat signifikansi sebesar 0.0184 yang berarti lebih kecil dari nilai alpha 0.05. Hasil penelitian ini sejalan dengan penelitian yang dilakukan oleh Alfinur (2016) bahwa kepemilikan manajerial berpengaruh negatif dan signifikan terhadap nilai perusahaan.

2. Pengaruh Kepemilikan Institusional terhadap Nilai Perusahaan

Hasil pengujian untuk hipotesis kedua menunjukkan bahwa kepemilikan institusional memiliki pengaruh positif dan signifikan terhadap nilai perusahaan. Hal ini dapat dilihat dari tingkat signifikansi sebesar 0.0032 yang berarti lebih kecil dari nilai alpha 0.05 . Hasil penelitian ini mendukung penelitian yang dilakukan oleh Sari dan Riduwan (2012) dan Muryati dan Suardikha (2014) bahwa kepemilikan institusional berpengaruh positif dan signifikan terhadap nilai perusahaan.

\section{Pengaruh Dewan Direksi terhadap Nilai Perusahaan}


Hasil pengujian untuk hipotesis ketiga menunjukkan bahwa dewan direksi tidak memiliki pengaruh yang signifikan terhadap nilai perusahaan. Hal ini dapat dilihat dari tingkat signifikansi sebesar 0.7032 yang berarti lebih besar dari nilai alpha 0.05 . Hasil penelitian ini senada dengan penelitian yang dilakukan oleh Agustiani (2016) yang menyatakan bahwa ukuran dewan direksi tidak memiliki pengaruh yang signifikan terhadap nilai perusahaan.

4. Pengaruh Dewan Komisaris Independen terhadap Nilai Perusahaan

Hasil pengujian untuk hipotesis keempat menunjukkan bahwa dewan komisaris independen memiliki pengaruh negatif dan signifikan terhadap nilai perusahaan. Hal ini dapat dilihat dari tingkat signifikansi sebesar 0.0147 yang berarti lebih kecil dari nilai alpha 0.05 .

Hasil penelitian ini sejalan dengan penelitian yang dilakukan oleh Widyasari, Suhandak dan Husaini (2015) bahwa komisaris independen memiliki pengaruh yang negatif dan signifikan terhadap nilai perusahaan.

5. Pengaruh Komite Audit terhadap Nilai Perusahaan

Hasil pengujian untuk hipotesis kelima menunjukkan bahwa komite audit tidak memiliki pengaruh yang signifikan terhadap nilai perusahaan. Hal ini dapat dilihat dari tingkat signifikansi sebesar 0.2808 yang berarti lebih besar dari nilai alpha 0.05 .

Hasil penelitian ini mendukung penelitian yang dilakukan oleh Anggraini (2013) dan Susanto dan Subekti (2013) yang menyatakan bahwa komite audit tidak berpengaruh terhadap nilai perusahaan.

6. Pengaruh Kepemilikan Manajerial, Kepemilikan Institusional, Dewan Direksi, Dewan Komisaris Independen dan Komite Audit terhadap Nilai Perusahaan

Hasil pengujian untuk hipotesis keenam menunjukkan bahwa kepemilikan manajerial, kepemilikan institusional, dewan direksi, dewan komisaris independen dan komite audit secara bersama-sama memiliki pengaruh yang signifikan terhadap nilai perusahaan. Hal ini dapat dilihat dari nilai signifikansi pada uji $\mathrm{F}$ sebesar $0.000<$ 0.05 . Hal ini berarti bahwa nilai perusahaan akan meningkat jika kelima variabel corporate governance secara bersama-sama mengalami peningkatan, dan sebaliknya nilai perusahaan akan menurun apabila variabel corporate governance secara bersama-sama mengalami penurunan.

\section{SIMPULAN}

Berdasarkan hasil uij statistik dan analisis penelitian yang telah dilakukan, dapat disimpulkan sebagai berikut:

1. Kepemilikan Manajerial memiliki pengaruh yang signifikan terhadap Nilai Perusahaan.

2. Kepemilikan Institusional memiliki pengaruh yang signifikan terhadap Nilai Perusahaan.

3. Dewan direksi tidak memiliki pengaruh yang signifikan terhadap Nilai Perusahaan.

4. Dewan Komisaris Independen memiliki pengaruh yang signifikan terhadap Nilai Perusahaan.

5. Komite Audit tidak memiliki pengaruh yang signifikan terhadap Nilai Perusahaan.

6. Kepemilikan Manajerial, Kepemilikan Institusional, Dewan Direksi, Dewan Komisaris Independen dan Komite Audit memiliki pengaruh yang signifikan terhadap Nilai Perusahaan. 


\section{REFERENSI}

Agustiani, Rizki M. (2016). Pengaruh Good Corporate Governance, Return on Asset, Return on Equity, BOPO, dan Capital Adequacy Ratio terhadap Nilai Perusahaan Go Public di Bursa Efek Indonesia. Jurnal Ekonomi Bisnis, 21 (2), 131-135.

Aldino, Raja., Yusralaini dan Paulus, Sem. (2015). Pengaruh Corporate Governance terhadap Nilai Perusahaan pada Perusahaan Manufaktur yang Terdaftar di Bursa Efek Indonesia (BEI) 2010-2012. Jom Fekon, 2 (1), 1-15.

Alfinur. (2016). Pengaruh Mekanisme Good Corporate Governance (GCG) terhadap Nilai Perusahaan pada Perusahaan yang Listing di BEI. Jurnal Ekonomi Modernisasi (JEM), 12 (1), 44-50.

Anggraini, Dina. (2013). Pengaruh Good Corporate Governance Terhadap Nilai Perusahaan pada Perusahaan Textile, Garment yang Terdaftar di Bursa Efek Indonesia (BEI) Periode 2009-2012. http://jurnal.umrah.ac.id/wp-content/uploads/2013/09/DinaAnggraini-090462201089.pdf. Diakses 2 November 2017.

Astuti, Alfira M. (2010). Fixed Effect Model pada Regresi Data Panel. Beta, 3 (2), 134-145.

Ghozali, Imam. (2009). Aplikasi Analisis Multivariate dengan Program SPSS, Cetakan IV. Semarang: Badan Penerbit Universitas Diponegoro.

Muryati, Ni N. T. S., dan Suardikha, I. M. S. (2014). Pengaruh Corporate Governance pada Nilai Perusahaan. E-Jurnal Akuntansi Universitas Udayana, 9 (2), 411-429.

Ningtyas, Kilat L., Suhadak dan Nuzula, Nila F. (2014). Pengaruh Good Corporate Governance terhadap Nilai Perusahaan (Studi pada Perusahaan yang terdaftar di Jakarta Islamic Index tahun 2010-2013). Jurnal Administrasi Bisnis (JAB), 17 (1), 19.

Rofina, Maria dan Priyadi, Maswar Patuh. (2013). Pengaruh Penerapan Good Corporate Governance Terhadap Kinerja Keuangan Perusahaan di BEI. Jurnal Ilmu \& Riset Akuntansi, 2 (1).

Sari, Enggar F. V., dan Riduwan, Akhmad. (2012). Pengaruh Corporate Governance terhadap Nilai Perusahaan: Kualitas Laba sebagai Variabel Intervening. Jurnal Ilmu dan Riset Akuntansi, 1 (1).

Sari, Truely P. dan Sedianngsih. (2014). Pengaruh Good Corporate Governance terhadap Kinerja Keuangan dan Nilai Perusahaan pada Peserta Survei Corporate Governance Perception Index. Jurnal Ekonomi dan Bisnis, 2, 159-165.

Singarimbun, Masri dan Sofian, Effendi. (2006). Metode Penelitian Survey, Cetakan Kedelapanbelas, Edisi Revisi. Jakarta: PT Pustaka LP3ES Indonesia.

Surya, Indra \& Yustiavandana, Ivan. (2006). Penerapan Good Corporate Governance Mengesampingkan Hak-Hak Istimewa demi Kelangsungan Usaha. Jakarta: Prenada Media Group.

Susanto, Priyatna B. dan Subekti, Imam. (2013). Pengaruh Corporate Social Responsibility dan Good Corporate Governance terhadap Nilai Perusahaan. http://jimfeb.ub.ac.id/index.php/jimfeb/article/viewFile/410/ 355. Diunduh 20 November 2017.

Trisnantari, Ayu N. (2010). Pengaruh Corporate Governance Pada Hubungan Pergantian Chief Executive Officer dengan Kinerja Perusahaan. Tesis, Universitas Udayana, Denpasar.

Widyasari, Nita A., Suhadak, dan Husaini, Achmad. (2015). Pengaruh Good Corporate Governance (GCG) dan Pengungkapan Corporate Social Responsibility (CSR) terhadap Nilai Perusahaan (Studi pada Perusahaan Manufaktur yang Terdaftar di BEI Periode 2011-2013). Jurnal Administrasi Bisnis (JAB), 26 (1), 1-10. 
